\title{
African Solutions to African Problems? The AU, R2P and Côte d'Ivoire
}

\author{
Ella Abatan and Yolanda Spies* \\ University of Pretoria, South Africa \\ ${ }^{*}$ Corresponding author. Email: ykspies@gmail.com
}

\begin{abstract}
The African continent is inextricably linked to development of the Responsibility to Protect $(R 2 P)$ norm and the latter's ethical interpretation of the duties associated with state sovereignty. With the African Union (AU) having institutionalised $R 2 P$ in its legalinstitutional foundation of 2000, the stage seemed set for the new African Peace and Security Architecture to demonstrate the continent's ramped-up interventionist approach to security. One of the first cases that presented an opportunity to do so, was the humanitarian crisis that erupted after the 2010 elections in Côte d'Ivoire. As the crisis unfolded, however, it became clear that the AU was not only unable to operationalise its institutionalised R2P mechanisms, but indeed reluctant to invoke $R 2 P$ explicitly. This raises serious concerns about the AU's willingness to intervene in its member states when humanitarian atrocities are perpetrated by governments against their own people. and throws into serious doubt the AU's promise to provide 'African solutions to African problems'.
\end{abstract}

Key words: African solutions, African Union, Côte d'Ivoire, Responsibility to Protect, peace and security, intervention, France, United Nations Security Council. 


\section{Introduction}

The year 2015 marked exactly a decade since world leaders endorsed the Responsibility to Protect (R2P) as part of the United Nations World Summit Outcome Document (WSOD). ${ }^{1}$ For Africans, the advent of 'codified R2P' at the intergovernmental level actually predated the WSOD by five years, because in 2000 the African Union (AU) enshrined the principle (if not the same terminology ${ }^{2}$ ) in its charter: ${ }^{3}$ Article 4(h) of the AU Constitutive Act established 'the right of the Union to intervene in a member state pursuant to a decision of the Assembly in respect of grave circumstances, namely war crimes, genocide and crimes against humanity'.

The AU's inclusion of this mandate was an acknowledgment, first, that Africa hosted a disproportionately large share of such 'grave circumstances' and second, that humanitarian crises could, in many cases, be attributed to violence orchestrated and perpetrated by incumbent governments against their own citizens. Article 4(h) confirmed growing concern that the traditional state-centric view of security - with its sacrosanct notion of sovereignty provided an impenetrable shield for abusive governments. ${ }^{5}$

A year after the AU Constitutive Act was adopted, the International Commission on Intervention and State Sovereignty (ICISS) published their landmark report in which the concept of state sovereignty was linked inextricably to the 'Responsibility to Protect'. ${ }^{6}$ Providing much more detail and depth, the report was essentially a global level 'thesis' of Article 4(h). Indeed, African crises, most notably the Rwandan genocide of 1994, had been catalytic in the global reconsideration of the normative parameters of sovereignty, and African scholars and diplomats (Francis Deng, Kofi Annan and Mohamed Sahnoun, inter alia) were instrumental in the conceptual development of $\mathrm{R} 2 \mathrm{P}{ }^{7}$ More generically, African values such as Pan-Africanism and Ubuntu ensured that R2P 'resonate[d] with a wide variety of indigenous and endogenous conceptions of community responsibility on the continent'. In short, the R2P concept seemed to be immutably and inimitably associated with Africa. ${ }^{9}$

With the AU having received a much broader peace and security mandate than its predecessor, the Organization of African Unity (OAU), and having institutionalised R2P at the legal-political level of the organisation, the stage seemed set for the new AU Peace and 
Security Architecture (APSA) to adopt a much more interventionist security approach and to provide 'African solutions to African problems'. ${ }^{10}$

One of the first cases that presented an opportunity for the AU to demonstrate its hands-on, accountable embrace of R2P, was the humanitarian crisis that erupted after the 2010 elections in Côte d'Ivoire. The international community was watching the crisis unfold and a range of actors called for operationalisation of the protection norm that world leaders had endorsed in 2005. The AU would surely rise to the challenge - it was, in terms of Article 4(h) of its Constitutive Act and the subsidiarity stipulations of the global R2P framework, the most appropriate political actor to take leadership in the crisis. But, perplexingly, it did not; the wider international community, specifically France with UN Security Council (UNSC) backing, was at the forefront of the 2011 humanitarian intervention that ended the conflict

This article seeks to critically assess the reasons for this anomaly and to probe the AU's failure to provide an African solution in the case of a distinctly African problem - one that has not subsided, if current electoral trends in Côte d'Ivoire are anything to go by. At a time when Africa is faced with a number of potential 'Côte d'Ivoires', amidst a spate of 'third termism' attempts and more blatant coups d'etat, the AU's conduct in the course of its responsibility to protect Africans is a matter of critical importance.

\section{The international community and the 2010 post-electoral crisis in Côte d'Ivoire}

The root causes of Côte d'Ivoire's post-electoral conflict in 2010 date back to the early 1990s. This period was characterised by economic crisis in Côte d'Ivoire and a simultaneous rise in demands for social reform and democratisation. The introduction of multiparty politics expanded political space and induced fierce competition for political power among different ethnic groups in the country. The succession crisis that followed President Felix HouphouëtBoigny's death in 1993 (after more than three decades in power) worsened the situation. As a result, by the end of September 2002 Côte d'Ivoire had plunged into civil war. ${ }^{11}$

The international community responded promptly to the crisis. Several intergovernmental organisations including the UN, AU, and the Economic Community of West African States (ECOWAS), as well as state actors such as France and South Africa, assisted with resolution of the conflict and, by 2007, the civil war had ended. ${ }^{12}$ 
Nonetheless, the process leading up to the 2010 elections proved challenging and complex. While achievements were made on voter registration (albeit with irregularities and unrealistic targets) and the identification of Ivorian nationals, there was little progress made regarding the disarmament of rebel forces and government militia. However, postponement of the elections - for a seventh time - would have been unacceptable and provocative. ${ }^{13}$

In spite of logistical problems and the challenges mentioned above, Côte d'Ivoire's longawaited presidential election took place on 31 October 2010, with Laurent Gbagbo, Alassane Ouattara and Henri Konan Bédie running as candidates. Whilst the first round of elections occurred in an atmosphere free of violence, the second round pushed the country back to the brink of war. ${ }^{14}$ Announcing the results, the Independent Electoral Commission (IEC) proclaimed Ouattara the winner with $54 \%$ of the vote against Gbagbo's $46 \%{ }^{15}$

The election results were endorsed by the AU, ECOWAS and the UN. Unfortunately, and as critics had predicted, Gbagbo contested the results, claiming election fraud and vote-rigging in the northern opposition stronghold area. The Ivorian Constitutional Council then cancelled more than 660000 votes in seven areas favourable to Ouattara and proclaimed Gbagbo the winner of the elections. ${ }^{16}$ In the midst of the political stalemate, the country once again descended into violence, with large scale loss of life and displacement of people.

By 24 March 2011 the UN Under-Secretary-General for Humanitarian Affairs and Emergency Relief Coordinator, Valerie Amos, confirmed that 'more than 460 people have been killed, and many more wounded... An estimated 500000 people have been displaced inside the country, and over 90000 have fled the country'. ${ }^{17}$ By June 2011, some 187266 Ivorians had fled the country and the death toll had increased to more than $3000 .^{18}$

For the most part, the international community stood united in recognising Ouattara as the elected president of Côte d'Ivoire and in condemning the acts of violence against civilians. However, judged by the background to the conflict and the sheer amount of information available prior to the elections, the parties themselves and the international community failed to adhere to the first (and arguably most important) sub-responsibility of R2P, namely the responsibility to prevent. 
In their analysis of the conflict, various commentators identified the warning signs of a disputed election based on the level of polarisation that existed prior to the election, and the fact that neither side was prepared to accept defeat. ${ }^{19}$ Furthermore, it is well-known that a substantive number of elections in Africa are marred by conflict; according to the Centre for Conflict Resolution (CCR) and the Friedrich Ebert Stiftung (FES), ${ }^{20}$ violence plagues between 19 and $25 \%$ of elections. Post-electoral violence or the fear thereof is rife in Africa. A sobering consideration is also that, since 2002 , the various peace agreements had all failed to deal with the underlying causes of the civil war. The international community was therefore forewarned about the crisis in Côte d'Ivoire.

\section{Regional responses to the crisis}

The Ivorian crisis in a number of ways represented a real threat to regional peace and stability. First, a spill-over of the conflict would be devastating for neighbouring Liberia and Sierra Leone; both already vulnerable as a result of protracted intra-state conflicts. Second, for the AU and ECOWAS to allow Gbagbo's intransigence and violation of the democratic process would set a dangerous precedent, given that 18 African countries were conducting elections during $2011 .{ }^{21}$ Last but not least, a situation of 'one country two presidents' would contradict both the AU and ECOWAS' principles on elections and democracy. ${ }^{22}$

On 4 December 2010, AU Commission Chairperson Jean Ping appointed former South African President Thabo Mbeki as mediator. While Mbeki was busy advocating for a negotiated settlement (in vain, as it turned out) the AU Peace and Security Council (PSC) on 9 December 2010 endorsed the results of the election, recognising Ouattara as the elected President of Côte d'Ivoire. The organisation also suspended Côte d'Ivoire from all its activities in accordance with Article 4 (p) of its Constitutive Act. ${ }^{23}$

Replacing Mbeki, on 27 December 2010 the AU appointed former Kenyan Prime Minister Raila Odinga as mediator. Odinga's efforts were, however, also unsuccessful, as were the subsequent attempts by AU chairperson Bingu wa Mutharika. Cognisant of these failures, the PSC met on 28 January 2011 and established the High-Level Panel for the Resolution of the Côte d'Ivoire Crisis, comprising heads of state of Tanzania, Burkina-Faso, Chad, Mauritania and South Africa as well as the Chairperson of the AU Commission (Jean Ping) and the president of the ECOWAS Commission (James Victor Gbeho). The Panel was mandated to 
'evaluate the situation and formulate, on the basis of relevant AU and ECOWAS decisions, an overall political solution'. ${ }^{24}$ After several visits to the country, on 9 and 10 March the Panel reported their findings and recommendations to the PSC - a month after the initial deadline. $^{25}$

The High-Level Panel affirmed its support for Ouattara, condemned the escalating humanitarian crisis, guaranteed a safe exit for Gbagbo, and advocated for a political solution to the crisis through the establishment of a government of national unity led by Ouattara, as well as the implementation of the pending aspects of the Ouagadougou Peace Agreement and other related reforms. ${ }^{26}$ Interestingly, however, despite Gbagbo's rejection of the Panel's recommendations, the AU went ahead and appointed Jose Brito as the AU High Representative charged with implementing the political solution. To make matters worse, Ouattara rejected his appointment, citing Brito's ties with Gbagbo. At this point it became obvious that the AU had arrived at an impasse. ${ }^{27}$

At the sub-regional level, efforts to resolve the crisis were also fruitless. From 7 December 2010 to 24 March 2011, ECOWAS executives held several meetings with Ouattara and Gbagbo. ${ }^{28}$ However, these meetings failed to change the parties' hardline positions and to stop the escalating humanitarian crisis.

As a result, and self-proclaiming its inability to solve the Ivorian crisis, ECOWAS during its summit on 24 March 2011 requested the UNSC 'to strengthen the mandate of UNOCI, enabling the mission to use all necessary means to protect life and property'. ${ }^{29}$ While observers such as $\mathrm{Yabi}^{30}$ allege that ECOWAS undermined its own credibility by turning to the UN, the organisation's decision appeared to be a sound reflection of the overwhelming challenges it faced.

\section{The UN and France's responses to the crisis}

The situation in Côte d'Ivoire changed considerably when Ouattara formed the Forces Republicaines de Côte d'Ivoire (FRCI) on 17 March 2011 and the fighting between Gbagbo and FRCI militias escalated, with widespread and massive human rights violations. The attacks on civilians in the town of Duékoué from 28 to 29 March resulted in some of the worst cases of mass killing and human rights violations that occurred during the conflict. As a 
result, and as the FRCI advanced, the need for protection of civilians from imminent threat

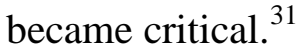

In the face of mounting violence and an apparent AU paralysis, on 30 May 2011 the UNSC unanimously passed Resolution 1975, imposing an asset freeze on Gbagbo and four of his associates. It urged Gbagbo to step down immediately and 'mandated UNOCI (United Nations Operation in Côte d'Ivoire) and supporting French forces to use all necessary means to protect civilians under imminent threat to physical violence... and to prevent the use of heavy weapons against the civilian population' ${ }^{32}$ Both the AU and ECOWAS endorsed the Security Council resolution.

This marked the beginning of the military intervention by UNOCI and the French Licorne forces, ending on 11 April 2011 with the arrest of Gbagbo by FRCI and UN forces. Ouattara subsequently assumed the role of President of Côte d'Ivoire.

\section{The AU's engagement with other actors in relation to the Côte d'Ivoire crisis}

A critical assessment of the AU's engagement with ECOWAS, France, and the UNSC could shed light on the reasons why, contrary to general expectations, the AU was not at the forefront of initiatives to resolve a crisis in its own 'backyard'.

\section{The AU and ECOWAS: Opportunity missed to find an African solution to the Ivorian crisis}

Acknowledging the importance of the security-development nexus, ECOWAS had reviewed its institutional policies and in 1999 adopted the Protocol Relating to the Mechanism for Conflict Prevention, Management, Resolution, Peacekeeping and Security which, in 2001, was supplemented by the Protocol on Democracy and Good Governance. ${ }^{33}$ Therefore, by the time the Ivorian post-electoral crisis erupted, ECOWAS had the regional legitimacy and arguably the potential and capacity to intervene diplomatically and militarily to protect civilians and end the conflict. This begs the question then of why it was the French Licorne forces working alongside UNOCI that led the military intervention instead of ECOWAS or the AU. 
An important obstacle was the ambiguity regarding AU-ECOWAS relations in ending the crisis. On the one hand, the two organisations seemed to have cooperated during their respective undertakings to resolve the conflict. For instance, on 17 December 2010 AU Commission Chair, Jean Ping, and the AU Commissioner for Peace and Security, Ramtana Lamamra, travelled to Abuja where they consulted with the Chair of ECOWAS, Nigerian President Goodluck Jonathan, before departing for negotiations in Abidjan accompanied by ECOWAS Commission President, Victor Gbeho. In addition, on 29 January 2011 Ping and Jonathan co-chaired the AU High-Level Meeting on Côte d'Ivoire. After the appointment of the AU High-Level Panel, Gbeho on 22 February 2011 joined the panel in Abidjan. ${ }^{34}$

Yet, the role played by and the impact of each of the organisations during these meetings are unclear and not explained in the various resolutions they adopted. The ambiguity might be explained by the fact that the individuals mentioned - in their capacities as Chair of the AU Commission, the AU Commissioner for Peace and Security, and Chair of ECOWAS - were not able to translate or convey what was agreed upon during their various meetings back to their respective organisations. It might also have been the result of a lack of coordination and direct discussions at the highest level of the two organisations. Throughout the conflict, apart from the initiatives previously described, it seems that no opportunity was created for the AU and ECOWAS to come together to discuss, and jointly take decisions about, appropriate measures to resolve the crisis.

Aning and Atuobi ${ }^{35}$ conclude that the lack of unity of response, duplication of efforts and confusion between the two regional bodies that were supposed to find an African solution to the Ivorian crisis, hindered their effectiveness and any leadership role they could have played. Undertaking different ad hoc mediation initiatives, with no clear line of cooperation and coordination, undermined their efforts to resolve the conflict and decreased the bargaining power associated with a coordinated strategy. ${ }^{36}$

ECOWAS' military chiefs and member states knew the organisation could not undertake military intervention, hence their prudent request to the UNSC to take action. However, it was only after requesting the UNSC to fulfill its primary responsibility that ECOWAS requested the AU Commission to establish the AU-ECOWAS joint facilitation team. ${ }^{37}$ In sum, and not necessarily intentionally, ECOWAS undermined the AU's leadership role in resolving the conflict. 
In terms of subsidiarity, it would have been judicious for ECOWAS to take the lead in mediation - under a clearly defined AU mandate and official endorsement - because of its comparative advantage in the West African region. Given the non-existence of a rapid deployment force on the continent, a unified position would also have afforded them more leverage to take joint ownership of the various resolutions introduced by the UNSC.

\section{Why was France, rather than the AU, leading UN intervention to stop an African conflict?}

France's engagement and relations with Africa are complex and have revolved around the idea of Françafrique - a principle coined by Houphouët-Boigny in 1955 to characterise the warm and positive ties between his country and its (then) colonial master, France. However, as Arampoorthy ${ }^{38}$ recounts, with time 'Françafrique has become synonymous with the highly controversial policies undertaken by the presidencies of the Fifth Republic in shaping the political and economic agenda of the African continent in order to maintain French influence and interests'.

In the immediate aftermath of the first Ivorian civil war, during 2007, Nicolas Sarkozy assumed the French Presidency and one of his first foreign policy positions was to distance himself from the notion of Françafrique. However, and throughout his term in office, what was witnessed instead was continuity rather than rupture in France's policies in Francophone Africa. Côte d'Ivoire was a case in point. Wyss ${ }^{39}$ reminds us that 'Côte d'Ivoire is not just any of France's former African colonies... It is the second largest economy in West Africa after Nigeria. In Côte d'Ivoire, France has large investments, a permanent military base, and the largest expatriate community South of the Sahara'. As a result, and as in the first civil war starting in 2002, there was little doubt that France would continue to play an active role in resolving conflict in its prized former colony. Indeed, since 2002 France's military involvement in Côte d'Ivoire had become increasingly more pronounced, at first as a measure to protect French nationals and their interests by acting as a buffer zone between the north and the south of the country, and later (following ECOWAS' failure to broker an agreement) as a mediator through the Linas Marcoussis Agreement (LMA).

The French military presence in Côte d'Ivoire known as Operation Licorne (whose presence and role had been officially authorised by UNSC Resolution 1464 of 4 February 2003) turned 
out to be one of France's biggest and most costly military operations abroad. ${ }^{40}$ Bovcon $^{41}$ argues, with realist cynicism, that if anarchy remains the perpetual nature of the international system 'it is almost impossible to expect a state to contribute its material and human resources solely on humanitarian grounds'. Therefore, in the absence of an African solution to the crisis, France skillfully took advantage of the opportunity to determine the outcome of the conflict. ${ }^{42}$

Throughout the Ivorian conflict, France used astute diplomacy by making use of the legitimising UN multilateral framework to lobby and mobilise international support in its favour. To begin with, France is a permanent member of the Security Council, allowing it to influence the latter's agenda and decisions. It made use of this influence to initiate and draft almost all the UNSC resolutions on the situation in Côte d'Ivoire. ${ }^{43}$ Through active diplomacy France managed to get the support of all three African non-permanent member states serving on the UNSC at the time of the conflict - Nigeria, Gabon and South Africa for the adoption of Resolution 1975. In Nigeria's case, the country had raised the possibility of a military intervention since the beginning of the conflict, and its support of Resolution 1975 was thus a rational continuation of its policy. Gabon's vote could be credited to the close historical, cultural, economic and military ties with its former colonial ruler, political patronage relations aptly explained by Gardinier. ${ }^{44}$

South Africa's affirmative vote on Resolution 1975 was rather intriguing. It was the only one among the three African countries to raise concern about the results announced by the IEC and the automatic international recognition of Ouattara as the winner. The President of the ECOWAS Commission even accused South Africa of deploying a warship to Côte d'Ivoire in support of Gbagbo, an accusation South Africa categorically rejected. ${ }^{45}$

Although little is known about the content of the meeting between French President Sarkozy and South African President Zuma during the latter's state visit to France in March 2011 (at the height of the crisis in Côte d'Ivoire), many observers are of the opinion that Sarkozy contributed to changing President Zuma's position regarding resolution of the conflict. According to $\mathrm{Wyss}^{46}$ the French President was perhaps successful in this regard as a result of South Africa's 'isolation in the AU's Peace and Security Council'. 
When France received an official invitation from the UN Secretary-General for the French Licorne to support the resource-constrained and over-stretched UNOCI forces, ${ }^{47}$ the intervention was legitimized; the invitation provided opportunity for France to pursue its own interests under the aegis of a multilateral mandate.

Despite these realities, it is important to note that from the beginning of the conflict, regime change was the end goal of all the initiatives undertaken by the international community. By recognising Ouattara as the president-elect of Côte d'Ivoire, the AU, ECOWAS and the UN explicitly acknowledged that in order to solve the electoral deadlock, Gbagbo had to relinquish power. Moreover, it is unlikely that Resolution 1975 would have passed without strong regional support.

Furthermore, while the French intervention has been criticised as neo-imperialist by many Africans and various French (and other) commentators, it was nonetheless legal and legitimate. ${ }^{48}$ The French Licorne Force was officially requested to intervene alongside UNOCI by the UN Secretary-General, ${ }^{49}$ and the intervention occurred under UNSC Resolution 1975, adopted unanimously by the UNSC and supported by all three AU members on the UNSC (a scenario reminiscent of the adoption of UNSC Resolution 1973 that authorised NATO to intervene in Libya, just two months earlier).

Most importantly, as Zounmenou, Motsamai and Nganje ${ }^{50}$ argue, 'despite the doubts, the alternative of standing idly on the sidelines yet again would have added to the shameful long list of rejecting the collective responsibility to protect'.

\section{The $U N-A U$ relationship in handling the conflict}

An extensive review of the AU and UN communiqués, press releases, statements, decisions and resolutions on the issue of Côte d'Ivoire, reveals that the two organisations partially worked together, at least at the level of the UN Secretariat and the AU Commission and AU PSC level. For illustrative purposes, on 29 January 2011 UN Secretary-General (UNSG) Ban Ki-Moon co-chaired the High-Level Meeting on Côte d'Ivoire, with the Chairs of ECOWAS and the AU. Furthermore, in his report on the activities of the UN Office for West Africa (UNOWA), the UNSG provided a detailed outline of the liaison conducted by his office with the AU. ${ }^{51}$ 
While it is clear that the office of the UNSG cooperated with various AU entities at different stages of the conflict, it is less clear as to the nature of the roles played by the UN Secretariat, the Chair of the AU Commission, and the PSC Chair during these endeavours. The question also arises as to how effective these joint ventures were in creating synergy at the highest level of the AU and the UN, namely at the PSC and the UNSC level.

Unfortunately, specific details about the contribution of the UNSG and his special representatives are not clarified in the various reports. In order words, while the UNSG employed positive semantics (wording such as 'assist', 'consult', 'cooperate', 'contribute', and 'participate') there is no clarity on what exactly the UNSG and his special representatives did and how they did it. Neither the UNSG nor the PSC clarified this. In addition, during the conflict there was no consultative meeting between members of the UNSC and the PSC. The fourth consultative meeting took place on 9 July 2010, before the conflict, and the fifth almost a year later, on 21 May 2011, after the resolution of the conflict. ${ }^{52}$

Given these points, there was no guarantee that the interaction of the UN Secretary-General with the AU could influence decisions taken at the UNSC. Consequently, one cannot make a definitive conclusion regarding the outcome of this cooperation in terms of synergy and decision-making at the highest level of both organisations. At the same time, it is important to note that the UN Secretary-General throughout the conflict commended the efforts of the PSC and the AU High-Level Panel ${ }^{53}$. Moreover, on 5 April after Resolution 1975 was passed the PSC welcomed it and 'encouraged UNOCI to vigorously implement its mandate to protect civilians' ${ }^{54}$

From the foregoing, it can be concluded that while there was no direct PSC-UNSC consultation on the Ivorian crisis, the UN and the AU nonetheless supported each other's efforts and did not work against each other as was arguably the case during the Libyan intervention.

\section{The AU's handling of the conflict in terms of its commitment to Article 4(h)}

The humanitarian crisis that unfolded after the Ivorian election offered a unique opportunity for the AU to show its commitment to R2P and Article 4(h), and to find an African solution 
to the Ivorian conflict. But to what extent did the AU use each of its African Peace and Security Architecture (APSA) pillars to address the crisis?

\section{The Peace and Security Council and the Ivorian crisis}

After the outbreak of the conflict the PSC took a principled position and, as mentioned, suspended Côte d'Ivoire from all its activities. The PSC raised concern about the unfolding humanitarian crisis and called on all the parties to respect the electoral outcome and the will of the people. It particularly made a plea to Gbagbo to hand over power without delay to the internationally recognised winner of the elections, Ouattara. ${ }^{55}$ In its 28 January 2011 communique the PSC under the authority of the AU appointed a High-Level Panel for the resolution of the crisis in Côte d'Ivoire. Importantly, the PSC $^{56}$ stated that the panel's conclusions and recommendations would be 'binding on all the Ivorian parties'. However, the AU High-Level Panel report as it turned out took too long to develop and by the time it was finally published the situation had changed considerably and the Ivorian parties did not seem to take it seriously.

One cannot help but wonder if this instance of non-compliance with a PSC decision is an isolated case, or an indictment of the PSC's standing in Africa. Some critics are of the opinion that African leaders have deliberately kept the AU and its organs, especially the commission and the PSC, in a weak position vis-à-vis themselves. The problem here, as demonstrated in the Ivorian case, is that many AU member states do not uphold or respect the organisation's principles on the promotion of human rights, the consolidation of democratic institutions and culture, and good governance and the rule of law. ${ }^{57}$

A number of AU member states, many of whom have served on the PSC (the highest decision making body on peace and security in Africa) have governments that perpetrate human rights abuses against their own citizens and these governments use the traditional Westphalian principles of sovereignty and non-interference as a rhetorical shield against international accountability. ${ }^{58}$ In fact, Côte d'Ivoire itself was serving a two-year term on the PSC when the conflict broke out. Indeed, although the AU member states formally declared their commitment to R2P at the continental level, inter alia through the Ezulwini Consensus, many of them have not incorporated its provisions at the national level. Regrettably, the AU lacks an effective monitoring and sanctions system to punish non-compliance. ${ }^{59}$ 
Another important obstacle that impedes the AU's effectiveness is lack of unity. In the Ivorian case, following the electoral deadlock, Angola, Uganda, the Democratic Republic of Congo, Chad, The Gambia, Equatorial Guinea and South Africa sided with Gbagbo, contradicting the AU's position which requested Gbagbo's departure and respect of the

electoral outcome. ${ }^{60}$ Such tensions occur in any intergovernmental organisation dealing with competing national interests; nonetheless they undermined the credibility of the AU and its ability to reach consensus regarding the preferred line of action to end a humanitarian crisis.

Considering all this, it was not surprising that the PSC was not able to act authoritatively to resolve the Ivorian crisis.

\section{The Continental Early Warning System and the Ivorian crisis}

Based on analysis of the communiqués, press releases, speeches and reports of the former Chairperson of the AU Commission and the PSC, it is not clear if the Continental Early Warning System (CEWS) played any role in resolving the Ivorian conflict. Neither the Chairperson of the AU Commission nor the PSC - the two recipients of early warning from the CEWS - mentioned the CEWS in their various statements about the AU's efforts to resolve the conflict. In addition, it is not clear if the AU Liaison Office in Côte d'Ivoire was used as an alternative to the CEWS. According to the $\mathrm{PSC}^{61}$ the liaison office was mandated to 'represent the AU with the government of Côte d'Ivoire', to monitor the situation on the ground, and to support - in coordination with ECOWAS and the UN - the efforts of the Ivorian parties. No mention is made of the institutional link between the liaison office and the CEWS.

Nonetheless, regardless of the fact that information might have been omitted for political reasons, and in view of the fact that the early warning system is supposed to provide information to the PSC, an analysis of the PSC undertakings in resolving the conflict can shed light on the effectiveness of the CEWS. To begin with, prior to the elections the PSC in its Report on the evolution of the crisis exit process since the signing of the Ouagadougou Political Agreement of 28 June 2010 - five months before the elections - identified a number of unaddressed problems. ${ }^{62}$ However, after the first round of elections the PSC made no reference to the possibility of a contested second round. According to the Peace and Security 
Protocol, ${ }^{63}$ the CEWS is mandated 'to facilitate the anticipation and prevention of conflicts'. On this account, one can conclude that it may have been the CEWS that failed to anticipate and prevent the post-electoral crisis. However, due to the lack of information on the CEWS' role in the PSC handling of the conflict, one cannot conclusively determine whether the failure was at the level of early warning or at the level of early action or lack of will of the relevant decisions makers to act on the early warning provided.

All this notwithstanding, it is difficult to downplay the challenges currently facing the CEWS. Member states' insistence on sovereignty and non-interference often hinders the collection of reliable information on conflict markers within their domestic jurisdiction. Furthermore, the Regional Economic Communities (RECs), which must act as the complementary elements of the CEWS, function at different levels of development and operationalisation. ${ }^{64}$

\title{
The Panel of the Wise and the Ivorian crisis
}

According to the AU Peace and Security Protocol: ${ }^{65}$

\begin{abstract}
At the request of the Peace and Security Council or the Chairperson of the Commission, or at its own initiative, the Panel of the Wise shall undertake such action deemed appropriate to support the efforts of the Peace and Security Council and those of the Chairperson of the Commission for the prevention of conflict.
\end{abstract}

In the case of Côte d'Ivoire, the Panel of the Wise (PoW) conducted no pre-election visits to the country. After the outbreak of the conflict it published a communiqué at its $9^{\text {th }}$ meeting whereby it expressed concerns about the contested election and restated its support for the AU Commission's efforts to resolve the conflict. Apart from its words of encouragement, the PoW played little role in the resolution of the conflict and, to the contrary, seemed to have been sidelined. It did not pronounce itself and was not involved in any of the mediation efforts undertaken during the crisis intervention period. The obvious reason might be that it is a nascent organ of the APSA and has not yet developed an institutionalised mediation process. Another reason might be the lack of supportive resources in terms of staffing and funding. ${ }^{66}$ 
Instead of drawing on the PoW, the AU set up two ad hoc mediation processes to resolve the crisis. However, while the AU mediation efforts were symbolically important, the organisation's choice of mediators raised concerns and the appointment of Mbeki and Odinga, respectively, was puzzling on many accounts.

On the one hand, although Mbeki's mediation during the 2002 civil war achieved quick success, during the 2010-2011 crisis he was forced to withdraw following accusations of bias in favour of Gbagbo. ${ }^{67}$ Keeping this in mind, it is hard to imagine a scenario where he would have been able to convince the parties, especially the Ouattara camp, to accept his recommended negotiated settlement. In addition, from the beginning of the conflict it was highly unlikely that the parties and the international community would agree to a powersharing solution; this was so particularly because none of the parties was willing to engage in negotiation, let alone admit defeat. Furthermore, it can be argued that neither the AU nor ECOWAS nor the UN was willing to accept a power-sharing deal that would once again leave Gbagbo in power, especially because since 2003 the Ivorian government had been (ostensibly) a unity government with Gbagbo as president. ${ }^{68}$

On the other hand, Odinga prior to his appointment by the AU had publicly expressed partiality, and repeatedly criticised the AU's preference for a peaceful solution. Already on 17 December 2010, during a press conference ten days before his appointment as the AU Special Envoy, Odinga stated, 'Gbagbo must be forced out, even if it means by military force... The AU should not be lamenting all the time... The AU should develop teeth' ${ }^{69}$ Although his assessment of the situation might have been justifiable, it nonetheless highlights that prior to his appointment, Odinga had no faith in the mandate he was chosen to implement. It is important therefore to note that although Mbeki and Odinga's expertise and experience in mediation are not being questioned, it certainly did not help that both were partial towards one of the parties and at times openly contradicted the position of the AU.

To be clear, at the operational level every conflict situation is different and thus there cannot be 'a one size fits all solution' to mediation. However, hasty and ad hoc mediations, with no clarity regarding criteria for mediators' selection, have proven to be ineffective and unsustainable in preventing conflict on the continent. ${ }^{70}$ 


\section{The African Standby Force (ASF), the Military Staff Committee (MSC) and the Ivorian crisis}

The ASF is a multinational military force of the AU responsible for ensuring the prevention of atrocities, as well as supporting the implementation of the PSC and the AU's right to intervene through timely deployment. ${ }^{71}$ It is in line with this provision that an MSC was established 'to advise and assist the Peace and Security Council in all questions relating to military and security requirements'. ${ }^{72}$

An analysis of the AU's handling of the Ivorian crisis shows that the AU never saw the need to be advised by the MSC on the conflict, nor the need for an intervention by the ASF. To begin with, throughout the conflict and on numerous occasions the AU expressed concern over the humanitarian crisis. In the Report of the Peace and Security Council on its activities and the state of peace and security in Africa at the Seventeenth Ordinary Session of the Assembly of the Union, the PSC characterised the crisis as a 'bloodbath' ${ }^{73}$ In addition, during its $270^{\text {th }}$ meeting the PSC $^{74}$ 'expressed its deep concern over the grave humanitarian consequences caused by the deterioration of the security situation... The Council deplored the loss of many lives, condemned the violation of human rights and other abuses in the context of military conflict'. If the interpretations of the humanitarian crisis by the PSC are examined in relation to Article 4(h) of the AU Constitutive Act, the question that comes to mind is: when does a 'bloodbath' become a grave circumstance of war crimes, genocide and crimes against humanity? And at what stage, or how, do the AU and the PSC decide when the threshold of Article 4(h) has been reached, so that intervention becomes necessary?

It is surprising that throughout the conflict, and despite vocal concern over the humanitarian crisis the AU and the PSC barely mentioned Article 4(h) or the R2P. ${ }^{75}$ In other words, according to the AU's conceptualisation of the conflict, the Ivorian post-electoral crisis and subsequent human rights violations did not meet the requirements as set out by Article 4(h) the violence therefore did not pass the threshold of grave circumstances. This choice of the AU and the PSC, whether deliberate or not, was unfortunate, considering that the need for rapid military deployment to protect civilians from imminent mass atrocities - already anticipated by ECOWAS and reiterated by the UN Secretary-General's Special Advisers on the Prevention of Genocide and the Responsibility to Protect - was necessary and clearly called for. By the time the AU High-Level Panel reported on their findings and 
recommendations, the available policy options had rapidly narrowed down and it was obvious that diplomatic pressure alone would not suffice to end the crisis.

The delay and lack of political will to operationalise the $\mathrm{ASF}^{76}$ imply that the AU lacks the enforcement means to undertake forceful intervention when the need arises - as was the case with the Ivorian crisis. As a consequence of these shortcomings, the AU tends to avoid reference to Article 4(h) or the $\mathrm{R} 2 \mathrm{P}$, and when it undertakes peace missions they tend to be ad hoc, with no clear vision and sustainability. The fear of not being able to respond credibly with the proper and appropriate capabilities, and the probability of bringing greater risks might be a reason behind the AU's hesitancy to mention Article 4(h) or R2P in the case of Côte d'Ivoire. Notwithstanding these factors, due to the current level of instability and the recurrence of conflicts on the continent, the importance of the ASF cannot be overstated. Despite this reality, peace operations in Africa are underfunded. ${ }^{77}$

\section{The Peace Fund and the Ivorian crisis}

Consideration of the challenges facing the Peace Fund can help elucidate some of the problems the AU and its organs faced in its handling of the Ivorian conflict.

Since its genesis, the AU has suffered from a chronic and perpetual lack of financial resources. $^{78}$ While African leaders are among the most fervent supporters of 'African solutions to African problems', they have been reluctant to fund the AU. This remains a major obstacle to the organisation's development. As of January 2009, only twenty-three of the (then) $53 \mathrm{AU}$ member states were up to date with their contributions to the AU's regular budget. ${ }^{79}$ Additionally, 'between 2008 and 2011, African states provided only two per cent of the AU's Peace Fund to cover various activities in the field of peace and security'. ${ }^{80}$ This state of affairs has prevented the AU from operationalising the APSA. Importantly, also, it has played up the AU's overdependence on external donors. As Vorrath ${ }^{81}$ points out, between 2008 and 2011, 98 per cent of the AU's Peace Fund was provided by external donors. This begs the question: to whom is the AU accountable - its donors, the governments of its member states, or Africans in general? 


\section{Conclusion}

The scope of this article has not allowed for in-depth discussion of the wider African discourse on R2P, and it is important to note that there are many critics who consider R2P intervention to be a ruse used by powerful states to pursue their national interests. ${ }^{82}$ Notwithstanding the debate, one would expect that a normative concept that emerged from the continent of Africa, and which is enshrined in the charter of the AU and speaks directly to Africa's grim realities, would be invoked by African leaders to stop mass atrocities whenever and wherever they occur on the continent. The Ivorian post-election humanitarian crisis of 2010/2011 offered a text-book opportunity for the AU to show its commitment to Article 4(h) of its Constitutive Act, where R2P had been incorporated at the legal-institutional level a decade earlier. However, as it turned out, not one of the organisation's peace and security architecture components was utilised to any significant degree in responding to the crisis.

The pervasive lack of capacity within the organisation was clearly, as it continues to be, a major stumbling block to implementation of R2P in the case of Côte d'Ivoire. But surely, in the face of a capacity deficit, the AU should have spearheaded the appeal to the UN Security Council to intervene. The UNSC has primary responsibility for international peace and security and the AU could therefore, in full compliance with international law, have shifted the burden of intervention onto the UNSC.

The AU's political response to the crisis was even more troubling, and deeply incongruous. While Côte d'Ivoire was clearly an R2P case, the AU did not invoke the principle explicitly at any point during the conflict, and neither did it articulate a clear position on the possibility of military action. As R2P proponents would rush to point out, military intervention should only be considered as a last resort, when all other means have failed to protect populations at risk. In this regard it is important to recall that, inasmuch as the AU never considered military intervention, it welcomed UNSC Resolution 1975 which gave UNOCI an offensive mandate, and even encouraged UNOCI to 'vigorously' implement this mandate. It would seem that the AU was complacent about playing a secondary role not only to the UNSC, but even to ECOWAS (prior to the intervention) and France, throughout the crisis.

That being the case, the argument can be made that the AU's reluctance to invoke R2P or its own Constitutive Act's Article 4(h), had been a conscious omission. It also strengthens criticism that the organisation remains unwilling - and not simply unable - to intervene in any of its member states, regardless of the severity of the crisis. Despite its ostensible 
acceptance of the new, post-Cold War human-centred security paradigm, the security culture of the AU continues to prioritise sovereignty and non-interference over humanitarian considerations. As the case study of Côte d'Ivoire has shown, the AU has not (yet) operationalised its R2P commitment. The result is that the idea of 'African solutions to African problems' remains rhetoric rather than reality.

${ }^{1}$ UN (United Nations), 2005 World Summit Outcome Document (WSOD) A/60/150, 2005, <http://www.ilo.org/wcmsp5/groups/public/---dgreports/integration/documents/meetingdocument/wcms_079439.pdf>.

2 The authors would like to acknowledge the useful contribution of an anonymous peerreviewer, who pointed out that the 'difference between R2P and what underlies in Art. 4(h) goes beyond a difference of terminology. Article 4(h) rather enshrines the right to intervene, which - when interpreted in terms of humanitarian intervention - corresponds to the radical end of pillar 3 of R2P. In this vein, it would be important to identify that the AU members agreed on a much more radical understanding compared to R2P alongside the principle of non-intervention that was codified under Art. 4(g). What is rather of resemblance to R2P as an understanding is the principle of non-indifference that was adopted by the very same document. [By the same token] ... the main purpose of the ICISS was to change the discourse from states' right to intervene into a responsibility of individual states and the international community to protect populations'.

${ }^{3}$ Aning K \& Atuobi S, 'Responsibility to Protect in Africa: An analysis of the African Union's Peace and Security architecture', Global Responsibility to Protect, 1, pp. 90-113; Powell K \& Baranyi S. Delivering on the Responsibility to Protect in Africa: Roundtable Report, Canada: The North-South Institute, 2005, p.2.

${ }^{4} \mathrm{AU}$ (African Union), Constitutive Act of the African Union (AU), Lomé: AU, 2000, pp. 6-7.

${ }^{5}$ Luck EC, 'Sovereignty, choice, and the Responsibility to Protect', Global Responsibility to Protect, 1, 2009, pp. 10-21; Williams PD, Security studies: an introduction, Oxon: Routledge, 2008, pp. 1-5; Williams PD, The Responsibility to Protect, norm localisation, and the African International society, London: Chatham House, 2009b, pp.397-398.

6 ICISS (International Commission on Intervention and State Sovereignty), The Responsibility to Protect, Ottawa: International Development Research Centre, 2001. 
${ }^{7}$ Deng F et al., Sovereignty as Responsibility: Conflict Management in Africa, Washington: Brookings, 1996, p. 4; Annan KA, We the peoples: the role of the United Nations in the 21st century. The millennium report of the UN Secretary-General, New York: The Department of Public Information, 2000; Bellamy AJ, Responsibility to Protect, Cambridge: Polity Press, 2009, p.76.

8 Williams PD, The Responsibility to Protect, norm localisation, and the African International society, London: Chatham House, 2009b, p.398.

${ }^{9}$ Spies Y \& Dzimiri P, 'A conceptual safari: Africa and the R2P', Regions \& Cohesion, 1, 1, 2011, pp. 32-53.

${ }^{10}$ Bellamy AJ, Responsibility to Protect, Cambridge: Polity Press, 2009, p. 78; Landsberg C, 'Reflections on the African Union after decade one: Looking back in order to look forward', The African Union at 10 years, Pretoria: Africa Institute of South Africa, 2012a, p.7; RuizGimenez A, The new African peace and security architecture: Evolution, opportunities and challenges, Madrid: African Studies Group - Autonomous University of Madrid, 2011, pp. 12.

${ }^{11}$ Akindès F, 'South African mediation in the Ivorian crisis', in Shillinger K (ed.), Africa's peacemaker? Lessons from South African conflict mediation, Johannesburg: Fanele, 2009, p. 120.

12 Ibid., pp. 123-126; Yabi G, Keeping the Peace in Electoral Conflicts: The Role of ECOWAS, UNOCI and the International Community in Côte d'Ivoire, Accra: Center for International Peace Operations, 2012, pp. 1-2.

${ }^{13}$ Boutellis A, The security sector in Côte d'Ivoire: a source of conflict and a key to peace, New York: International Peace Institute, 2011, pp. 9-11; de Tessières S, 'Reforming the ranks: public security in a divided Côte d'Ivoire', In Small Arms Survey, Geneva: The Graduate Institute, 2011, pp. 200-207.

${ }^{14}$ Zounmenou DD \& Lamin AR, 'Côte D'Ivoire's Post-electoral Crisis: Ouattara Rules but can he Govern?', Journal of African Elections, 10, 2, 2011, pp. 6-21.

${ }^{15}$ Langer A, Côte d'Ivoire's elusive quest for peace, Dublin: University College Dublin, 2010 , p. 14. 
16 The Carter Center, International election observation mission in Côte d'Ivoire, Atlanta: Carter Center, 2011, p. 9; Bellamy AJ \& Williams PD, 'The new politics of protection? Côte d'Ivoire, Libya and the Responsibility to Protect', International Affairs, 87, 4, 2011, p. 832.

${ }^{17}$ UNOCHA (United Nations Office for the Coordination of Humanitarian Affairs), United Nations humanitarian chief alarmed at deterioration in Côte d'Ivoire, New York: OCHA, 2011, p. 1.

${ }^{18}$ UNGA (United Nations General Assembly), A/HRC/16/79 Report of the United Nations High Commissioner for human rights on the situation of human rights in Côte d'Ivoire, New York: UN, 2011; UNGA (United Nations General Assembly), A/HRC/19/72 Report of the independent expert on the situation of human rights in Côte d'Ivoire, Doudou Diène, New York: UN, 2012, p. 5.

${ }^{19}$ Langer A, Côte d'Ivoire's elusive quest for peace, Dublin: University College Dublin, 2010, p. 1; Martins V, 'The Côte d'Ivoire crisis in retrospect', Portuguese Journal of International Affairs, 5, 2011, p. 82; Nganje F \& Check N, The Crisis in Côte d'Ivoire: What lessons for Africa and the International Community?, South Africa: The Africa Institute of South Africa (AISA) and the Institute for Global Dialogue (IGD), 2011, p. 4; Straus S, 'It's sheer horror here: patterns of violence during the first four months of Côte d'Ivoire's postelectoral crisis', African Affairs, 110, 440, 2011, p. 489; The Carter Center, International election observation mission in Côte d'Ivoire, Atlanta: Carter Center, 2011, p. 65; Zounmenou DD \& Lamin AR, 'Côte D'Ivoire's Post-electoral Crisis: Ouattara Rules but can he Govern?', Journal of African Elections, 10, 2, 2011, pp. 8-9.

${ }^{20}$ CCR (Centre for Conflict Resolution) \& FES (the Friedrich Ebert Stiftung), The African Union at ten: problems, progress, and prospects, Berlin: Centre for Conflict Resolution and the Friedrich Ebert Stiftung, 2012, p. 26.

${ }^{21}$ Kent-Brown D et al., Peace and Security Council Protocol No. 19, Addis Ababa: ISS, 2011, p. 12.

${ }^{22}$ Cooke JG, The election crisis in Côte d'Ivoire, 2010, http://csis.org/publication/electioncrisis-ivory-coast.

${ }^{23}$ AU PSC (African Union Peace and Security Council), Report on the evolution of the crisis exit process in Côte d'Ivoire since the signing of the Ouagadougou political agreement, Addis Ababa: AU, 2010a, p. 3. 
${ }^{24}$ AU PSC (African Union Peace and Security Council), Report of the chairperson of the commission on the situation in Côte D'Ivoire PSC/PR/2 (CCLXXIII), Addis Ababa: AU, 2011c, p. 2.

${ }^{25}$ African Union Assembly, AU/4/XVII Assembly of the Union, seventeenth ordinary session. Report of the Peace and Security Council on its activities and the state of peace and security in Africa, Addis Ababa: AU, 2011, pp. 4-5; AU PSC (African Union Peace and Security Council), Report of the chairperson of the commission on the situation in Côte D'Ivoire PSC/ PR/2 (CCLXXIII), Addis Ababa: AU, 2011c, pp. 1-3.

${ }^{26}$ AU PSC (African Union Peace and Security Council), Report of the chairperson of the commission on the situation in Côte D'Ivoire PSC/PR/2 (CCLXXIII), Addis Ababa: AU, 2011c, p. 2.

${ }^{27}$ Apuuli KP, 'The African Union's notion of 'African solutions to African problems' and the crises in Côte d'Ivoire (2010-2011) and Libya (2011)', African Journal on Conflict Resolution, 12, 2, 2012, pp. 75-76. 1-186; African Union Assembly, AU/4/XVII Assembly of the Union, seventeenth ordinary session. Report of the Peace and Security Council on its activities and the state of peace and security in Africa, Addis Ababa: AU, 2011, pp. 4-5.

${ }^{28}$ ECOWAS, Extraordinary session of the Authority of Heads of State and Government on Côte d'Ivoire: final communiqué ECW/ABJ/EXT/FR.Rev.0, Abuja: ECOWAS, 2010a, p. 4; ECOWAS, Final communiqué on the Extraordinary session of the Authority of Heads of State and Government on Côte d'Ivoire $N^{0}: 188 / 2010$, Abuja: ECOWAS, 2010b.

${ }^{29}$ ECOWAS, Resolution A/RES.1/03/11 of the Authority of Heads of State and Government of ECOWAS on the situation in Côte d'Ivoire, Abuja: ECOWAS, 2011, p. 2.

${ }^{30}$ Yabi G, Keeping the Peace in Electoral Conflicts: The Role of ECOWAS, UNOCI and the International Community in Côte d'Ivoire, Accra: Center for International Peace Operations, 2012, p. 3.

${ }^{31}$ Bellamy AJ \& Williams PD, 'The new politics of protection? Côte d'Ivoire, Libya and the Responsibility to Protect', International Affairs, 87, 4, 2011, pp. 833-834;Straus S, 'It's sheer horror here: patterns of violence during the first four months of Côte d'Ivoire's post-electoral crisis', African Affairs, 110, 440, 2011, pp. 483-487.

32 UNSC (United Nations Security Council) S/RES/1975, Resolution 1975 adopted by the Security Council at its $6508^{\text {th }}$ meeting on 30 March 2011, New York: UN, 2011b; UNSC 
(United Nations Security Council) S/RES/1962, Resolution 1962 adopted by the Security Council at its $6458^{\text {th }}$ meeting on 20 December 2010, New York: UN, 2010; UNSC (United Nations Security Council) S/RES/1967, Resolution 1967 adopted by the Security Council at its $6469^{\text {th }}$ meeting on 19 January 2011, New York: UN, 2011a.

33 ECOWAS, Protocol relating to the mechanism for conflict prevention, management, resolution, peace-keeping and security, Lome: ECOWAS, 1999; ECOWAS, Protocol A/SP1/12/01 on Democracy and Good Governance Supplementary to the Protocol relating to the Mechanism For Conflict Prevention, Management, Resolution, Peacekeeping and Security, Dakar: ECOWAS, 2001.

34 UNSC (United Nations Security Council) S/2011/21, Twenty-Seventh progress report of the Secretary General on the United Nations Operation in Côte d'Ivoire, New York: UN, 2011c, pp. 6-8.

35 Aning K \& Atuobi S, The Role of Regional and Sub-regional Arrangements in Strengthening the Responsibility to Protect, New York: The Stanley Foundation, 2011, p. 13.

${ }^{36}$ Obi C, Africa and the challenges of the twenty-first century: ECOWAS-AU-UN relations with special reference to the Cote d'Ivoire crisis, CODESRIA: Morocco, 2011, p. 6; Yabi G, Keeping the Peace in Electoral Conflicts: The Role of ECOWAS, UNOCI and the International Community in Côte d'Ivoire, Accra: Center for International Peace Operations, 2012, p. 3.

${ }^{37}$ ECOWAS, Resolution A/RES.1/03/11 of the Authority of Heads of State and Government of ECOWAS on the situation in Côte d'Ivoire, Abuja: ECOWAS, 2011.

${ }^{38}$ Arampoorthy S, Will Nicolas Sarkozy's presidency mark the end of La Françafrique?, 2011, < $\quad$ http://www.e-ir.info/2011/10/30/will-nicolas-sarkozy\%E2\%80\%99s-presidencymark-the-end-of-la-francafrique/>.

${ }^{39}$ Wyss M, 'Primus inter pares? France and multi-actor peacekeeping in Côte d'Ivoire', In Tardy T \& Marco W (eds), Peacekeeping in Africa: the evolving security architecture, Oxon: Routledge, 2014, p. 133.

40 Bovcon M, 'Françafrique and regime theory', European Journal of International Relations, 19, 1, 2011, p. 20.

41 Bovcon M, 'France's Conflict Resolution Strategy in Côte d'Ivoire and its Ethical Implications', African Studies Quarterly, 11, 1, 2009, p. 14. 
${ }^{42}$ Nganje F \& Check N, 'The Crisis in Côte d'Ivoire: What lessons for Africa and the International Community?', South Africa: The Africa Institute of South Africa (AISA) and the Institute for Global Dialogue (IGD), 2011, p. 10.

${ }^{43}$ Wyss M, 'The gendarme stays in Africa: France's military role in Côte d'Ivoire', African conflict and peacebuilding review, 3, 1, 2013, pp. 95-96.

44 Gardinier ED, 'France and Gabon since 1993: The reshaping of a neo-colonial relationship', Journal of Contemporary African Studies, 18, 2, 2000.

${ }^{45}$ Kikoler N, 'Supporting African problems. IBSA and the implementation of Article 4(h)', In Kuwali D \& Viljoen F (eds), Africa and the Responsibility to Protect: Article 4(h) of the African Union Constitutive Act, 2014, p. 334;Obi C, Africa and the challenges of the twentyfirst century: ECOWAS-AU-UN relations with special reference to the Cote d'Ivoire crisis, CODESRIA: Morocco, 2011, pp. 14-15.

${ }^{46}$ Wyss M, 'The gendarme stays in Africa: France's military role in Côte d'Ivoire', African conflict and peacebuilding review, 3, 1, 2013, p. 97.

${ }^{47}$ UNSG (United Nations Secretary General), Statement by the Secretary-General on the situation in Côte d'Ivoire, 2011, <http://www.un.org/sg/statements/?nid=5196> .

${ }^{48}$ Wyss M, 'The gendarme stays in Africa: France's military role in Côte d'Ivoire', African conflict and peacebuilding review, 3, 1, 2013, p. 82; Zounmenou DD, Côte d'Ivoire's postconflict challenges, South Africa: African Centre for the Constructive Resolution of Disputes (ACCORD), 2011, p. 31.

49 UNSG (United Nations Secretary General). Statement by the Secretary-General on the situation in Côte d'Ivoire, 2011, <http://www.un.org/sg/statements/?nid=5196> .

${ }^{50}$ Zounmenou DD et al., $A U$ and the Responsibility to Protect: the cases of Libya and Cote d'Ivoire, New York: The Wilson Center's Africa Program and Leadership Project and the Institute for Global Dialogue and ISS, 2012, p. 19.

${ }^{51}$ UNSC (United Nations Security Council) S/2011/388, Report of the Secretary General on the activities of the United Nations Office in West Africa, New York: UN, 2011d, pp. 5-6.

${ }^{52}$ AU PSC (African Union Peace and Security Council), Côte d'Ivoire Liaison Office, Addis Ababa: AU, 2012. 
${ }^{53}$ UNSC (United Nations Security Council) S/RES/1975, Resolution 1975 adopted by the Security Council at its 6508th meeting on 30 March 2011, New York: UN, 2011b.

${ }^{54}$ AU PSC (African Union Peace and Security Council), Press statement of the 270th meeting of the Peace and Security Council PSC/PR/BR.(CCLXX), Addis Ababa: AU, 2011b, p. 2.

${ }^{55}$ AU PSC (African Union Peace and Security Council), Communique of the 252nd meeting of the Peace and Security Council, Addis Ababa: AU, $2010 \mathrm{~b}$.

${ }^{56}$ AU PSC (African Union Peace and Security Council), Communique of the 259th meeting of the Peace and Security Council PSC/AHG/COMM(CCLIX), Addis Ababa: AU, 2011a, p. 3.

57 Williams PD, 'The Peace and Security Council of the African Union: evaluating an embryonic international institution', Journal of Modern African Studies, 47, 4, 2009a, p. 608. ${ }^{58}$ Landsberg C, 'Reflection on the African Union after decade one', Africa Insight, 42, 3, 2012b, p. 9; Murithi T, 'The African Union and the African Peace and security Architecture', Africa Insight, 42, 3, 2012, p. 51.

${ }^{59}$ Cilliers J, 'Hopes and challenges for the Peace and Security Architecture of the African Union, In Besada H (ed), Crafting an African Security Architecture: Addressing regional peace and conflict in the 21st century, England: Ashgate Publishing Limited, 2010, p. 49.

${ }^{60}$ Rupiya M, 'A review of the African Union's experience in facilitating peaceful power transfer: Zimbabwe, Ivory Coast, Libya and Sudan: are there prospects for reform?', African Journal on Conflict Resolution, 12, 2, 2012, p. 171; Apuuli KP, 'The African Union's notion of 'African solutions to African problems' and the crises in Côte d'Ivoire (2010-2011) and Libya (2011)', African Journal on Conflict Resolution, 12, 2, 201, pp. 151-152.

${ }^{61}$ AU PSC (African Union Peace and Security Council), Côte d'Ivoire Liaison Office, Addis Ababa: AU, 2012.

${ }^{62}$ AU PSC (African Union Peace and Security Council), Report on the evolution of the crisis exit process in Côte d'Ivoire since the signing of the Ouagadougou political agreement, Addis Ababa: AU, 2010a.

${ }^{63} \mathrm{AU}$ (African Union), Protocol Relating to the Establishment of the Peace and Security Council of the AU, Durban: AU, 2003, pp. 17-18. 
${ }^{64}$ CCR (Centre for Conflict Resolution) \& the FES (Friedrich Ebert Stiftung), The African Union at ten: problems, progress, and prospects, Berlin: Centre for Conflict Resolution and the Friedrich Ebert Stiftung, 2012, pp. 12-25; High Level Panel of the Audit of the African Union, Audit of the African Union, Addis Ababa: AU, 2007, pp. 126-137.

${ }^{65}$ AU (African Union), Protocol Relating to the Establishment of the Peace and Security Council of the AU, Durban: AU, 2003, p. 16.

${ }^{66}$ High Level Panel of the Audit of the African Union, Audit of the African Union, Addis Ababa: AU, 2007, p. 100; AU (African Union), Communique: 9th meeting of the Panel of the Wise, Addis Ababa: AU, 2010b, p. 32.

${ }^{67}$ Akindès F, 'South African mediation in the Ivorian crisis', in Shillinger K (ed.), Africa's peacemaker? Lessons from South African conflict mediation, Johannesburg: Fanele, 2009, p. 140.

${ }^{68}$ Martins V, 'The Côte d'Ivoire crisis in retrospect', Portuguese Journal of International Affairs, 5, 2011, pp. 75-76; Observatoire de 1'Afriques, The African Union's role in the Libya and Cote d'Ivoire conflicts: Africa briefing report, 2011, <http://www.obsafrique.eu/?p=1900>; Cooke JG, The election crisis in Côte d'Ivoire, 2010, $<$ http://csis.org/publication/election-crisis-ivory-coast>.

69 BBC News Africa, Ivory Coast: Gbagbo under pressure to stand down, 2010, $<$ http://archive.today/WpAo1>.

70 See for example Laurie Nathan's discussion of mistakes made during the Darfur mediation. Nathan L, No Ownership, No Peace: The Darfur Peace Agreement', Working Paper, series 2, no. 5, Crisis States Research Centre, 2006. For a more general discussion on the pitfalls of mediation in Africa, see Brahimi L. and Ahmed S, In Pursuit of Sustainable Peace: The Seven Deadly Sins of Mediation, Center on International Cooperation, New York University, 2008.

${ }^{71}$ AU (African Union), Protocol Relating to the Establishment of the Peace and Security Council of the AU, Durban: AU, 2003, pp. 18-19.

72 AU (African Union), Protocol Relating to the Establishment of the Peace and Security Council of the AU, Durban: AU, 2003, p. 20. 
${ }^{73}$ African Union Assembly, AU/4/XVII Assembly of the Union, seventeenth ordinary session. Report of the Peace and Security Council on its activities and the state of peace and security in Africa, Addis Ababa: AU, 2011, p. 5.

74 AU PSC (African Union Peace and Security Council), Press statement of the 270th meeting of the Peace and Security Council PSC/PR/BR.(CCLXX), Addis Ababa: AU, 2011b, p. 1.

75 Aning K \& Atuobi S, The Role of Regional and Sub-regional Arrangements in Strengthening the Responsibility to Protect, New York: The Stanley Foundation, 2011, pp. 14-15.

${ }^{76}$ AU (African Union), Progress report on the status of the operationalization of the African Standby Force, Addis Ababa: AU, 2010a.

${ }^{77}$ CCR (Centre for Conflict Resolution) \& FES (the Friedrich Ebert Stiftung), The African Union at ten: problems, progress, and prospects, Berlin: Centre for Conflict Resolution and the Friedrich Ebert Stiftung, 2012, pp. 12-25; High Level Panel of the Audit of the African Union, Audit of the African Union, Addis Ababa: AU, 2007 pp. 126-137.

78 Williams PD, 'The Peace and Security Council of the African Union: evaluating an embryonic international institution', Journal of Modern African Studies, 47, 4, 2009a, p. 618.

79 African Union Executive Council, Decision on the contribution of member states Doc.EX.CL/453(XIV), Addis Ababa: AU, 2009, p. 10.

80 Vorrath J, Imbalances in the African Peace and Security Architecture: The current approach to capacity-building needs to be challenged, Berlin: Stiftung Wissenschaft and Politik German Institute for International and Security Affairs, 2012, pp. 1-2.

${ }^{81}$ Ibid.

${ }^{82}$ Abass A. 'The African Union and the Responsibility to Protect: Principles and limitations', in Responsibility to Protect: From Principle to Practice, Hoffmann J and Nollkaemper A (eds), 213-236. Amsterdam: Pallas Publications, 2012, p. 218; Mbeki T, 'What the world got wrong in Côte d'Ivoire', in Foreign Policy, 2011, < http://www.foreignpolicy.com/articles/2011/04/29>. 